\title{
Serum antibodies to Pseudomonas aeruginosa outer- membrane proteins and iron-regulated membrane proteins at different stages of chronic cystic fibrosis lung infection
}

\author{
G. H. SHAND*, S. S. PEDERSEN, M. R. W. BROWNt and N. HøIBY
}

State Serum Institute, Department of Clinical Microbiology at Rigshospitalet, Juliane Maries Vej 28, 2., DK-2100, Copenhagen, Denmark and +Microbiology Research Group, Department of Pharmaceutical Sciences, Aston University, Aston Triangle, Birmingham B4 7ET

\begin{abstract}
Summary. Serum samples collected over periods up to 15 years from nine patients with cystic fibrosis $(\mathrm{CF})$ were investigated by immunoblotting and crossed immuno-electrophoresis (CIE) for antibodies to Pseudomonas aeruginosa outer-membrane proteins (OMPs). The earliest antibody response to OMPs was directed against proteins G, H1 and I. Detection by immunoblotting sometimes preceded the CIE response; the appearance of antibodies to the other major OMPs was co-incident with an increase in CIE precipitins. Isolation of the mucoid form of $P$. aeruginosa was associated with a rapid increase in both precipitin numbers and antibodies detected by immunoblotting. Antibodies to iron-regulated OMPs could be detected in all the serum samples that showed eight or more CIE precipitins but their presence became pronounced only in the advanced stages of disease. The clinical strain used in this study and other isolates from CF patients showed several atypical OMPs, perhaps as a consequence of antibiotic therapy or related to the serum sensitivity of mucoid $P$. aeruginosa. Their expression in vivo was confirmed by detecting antibodies to them in patients' serum.
\end{abstract}

\section{Introduction}

Although widely distributed in the environment, Pseudomonas aeruginosa rarely infects man in health. However, it is a major opportunist pathogen when normal immune mechanisms are impaired. ${ }^{1}$ Chronic $P$. aeruginosa lung infection is at present the major cause of death in cystic fibrosis (CF) patients ${ }^{2,3}$ because progressive destruction of infected lung leads to respiratory insufficiency. Several enzymes and toxins of $P$. aeruginosa are thought to be responsible for this destruction during the early stages of infection. ${ }^{4,5}$ Prolonged antigenic stimulation caused by the continuous presence of bacteria in the lungs exacerbates the direct damage because neutrophils and macrophages recruited to the site of infection break down, with local release of lysosomal enzymes and inflammatory mediators. ${ }^{6}$ Evidence is accumulating that immune complexes formed from antibodies and persisting bacteria can also mediate hypersensitivity reactions which further increase the lung damage. ${ }^{7}$ Although antibiotics rarely eradicate the bacteria from the lungs, ${ }^{8}$ regular courses of intensive treatment with antipseudomonal antibiotics improve lung function, patient well-being and long term survival. ${ }^{9,10}$ Therefore, it is important to identify the onset of chronic

Received 27 April 1990; revised version accepted 18 Aug. 1990.

* Present address for correspondence: Microbiology Department, Dakopatts A/S, PO Box 1359, DK-2600, Glostrup, Denmark. lung infection so that treatment can begin before tissue damage becomes extensive.

The serum antibody response to $P$. aeruginosa may be monitored by crossed immuno-electrophoresis $(\mathrm{CIE})^{3}$ with water soluble extracts of cell sonicates as antigen (standard antigen, StAg) when up to 64 precipitating antibodies to $P$. aeruginosa have been detected. ${ }^{11}$ Results from CIE studies indicate that a substantial antibody response is mounted in CF lung infection, ${ }^{12}$ that an increase in the number of precipitin peaks shown by CIE correlates with clinical deterioration and that this may be used as an indication for antibiotic treatment. ${ }^{3,9} \mathrm{CIE}$ shows the number of antigen-antibody reactions at different stages of the infection but has rarely been used to identify the antigens involved. ${ }^{11,13}$

The cell envelope of $P$. aeruginos a contains a number of macromolecules which may interact with host cells to produce an immune response. ${ }^{14}$ Outer-membrane proteins (OMPs) have been shown to be highly conserved in strains of $P$. aeruginosa of different $\mathrm{O}$ serotypes ${ }^{15}$ and the presence of antibodies to OMPs has been demonstrated in CF serum. ${ }^{16-18}$ However, these studies were not done with clinical isolates grown under iron-limited conditions such as prevail in vivo. Iron is essential to the growth of bacteria and mechanisms to acquire it are virulence factors in pathogenic and potentially pathogenic bacteria ${ }^{19}$ such as $P$. aeruginosa. ${ }^{20,21}$ Iron-regulated outer-membrane proteins (IRMPs), induced in iron-limited conditions, 
are thought to function as cell-surface receptors in high affinity uptake systems for iron-siderophore complexes. ${ }^{19,22}$ Antibodies to IRMPs have been reported in the serum of an infected CF patient. ${ }^{23,24}$

Our aim in this study was to investigate CF patients for antibodies to IRMPs by immunoblotting, and to determine how the chronological appearance of antibodies to OMPS and to IRMPs correlates with the duration of infection and the patient's clinical condition. Immunoblotting has been compared with CIE with $P$. aeruginosa $\mathrm{StAg}$.

\section{Materials and methods}

\section{Patients and treatment}

Diagnosis of CF was made on the basis of abnormal sweat electrolytes and exocrine pancreatic insufficiency. ${ }^{25}$ All patients in the study attended the outpatient clinic at the Danish CF Centre at Rigshospitalet at monthly intervals for bacteriological investigations and physical evaluation. The progress of the disease was charted by following the patient's records, including the results of sputum bacteriology, weight gain and lung function, and was correlated with changes in CIE precipitins.

Before 1976, antipseudomonal chemotherapy was given only when there was acute pulmonary exacerbation or clinical deterioration. Since 1976, all patients with chronic $P$. aeruginosa infection have been admitted to the Centre every 3-4 months for a 2-week course of intravenous antibiotics.

\section{Serum antibodies and sputum bacteriology}

Blood samples were obtained from patients at 3-4month intervals for examination of immune status. Serum samples not used immediately were stored at $-20^{\circ} \mathrm{C}$. Precipitating antibodies against $P$. aeruginosa were determined at least once a year by CIE.

$P$. aeruginosa was identified in sputum samples by standard criteria. A diagnosis of chronic bronchopulmonary infection was made when $P$. aeruginosa was cultured from bronchial secretions for 6 consecutive months or the number of precipitating antibodies was $\geqslant 2$ (normal values $0-1$ ) or both. ${ }^{11}$

Regularly spaced, sequential serum samples covering the stages of the disease from a time when there was no evidence of $P$. aeruginosa in respiratory secretions through to the late stages of chronic broncho-pulmonary infection were available from nine CF patients. Control sera were obtained from 10 young CF patients (average age 0.8 years) with no history of $P$. aeruginosa growth in sputum and 10 healthy adults with no history of infection due to $P$. aeruginosa.

Serum samples were defatted before immunoblotting by centrifugation at $5000 \mathrm{~g}$ for $10 \mathrm{~min}$ at $4^{\circ} \mathrm{C}$, whereupon any fat in the serum formed a milky white layer at the surface of the sample which was removed with a pipette.

\section{Bacteria and culture conditions}

$P$. aeruginosa strains used in the study were isolated from sputum samples of CF patients. The six strains chosen represent the phenotypes and serotypes most commonly isolated at the Danish CF Centre (table I). Bacteria were grown in a chemically defined medium (CDM) containing $40 \mathrm{mM}$ glucose, $40 \mathrm{mM}\left(\mathrm{NH}_{4}\right)_{2} \mathrm{SO}_{4}$, $3.2 \mathrm{mM} \mathrm{K}_{2} \mathrm{HPO}_{4} .3 \mathrm{H}_{2} \mathrm{O}, 0.62 \mathrm{mM} \mathrm{KCl}, 0.5 \mathrm{~mm} \mathrm{NaCl}$, $0.4 \mathrm{mM} \mathrm{MgSO}_{4} .7 \mathrm{H}_{2} \mathrm{O}$, and $50 \mathrm{~mm}$ 3-( $\mathrm{N}$-morpholino) propane sulphonic acid (MOPS). The $\mathrm{pH}$ of the medium was adjusted to 7.8 with $\mathrm{NaOH}$.

\section{Outer membrane (OM) preparation}

OMs were prepared by the method of Filip et al. ${ }^{26}$ Briefly, bacteria grown to early stationary phase at $35^{\circ} \mathrm{C}$ in $\mathrm{CDM}$ were harvested by centrifugation, resuspended in distilled water and broken by sonication in an ice bath. Unbroken cells were removed by centrifugation at $5000 \mathrm{~g}$ for $10 \mathrm{~min}$. Sarkosyl (Nlauroylsarcosine, sodium salt; Sigma), was added to the supernate to a final concentration of $2 \%$. The mixture was incubated for $30 \mathrm{~min}$ at $20^{\circ} \mathrm{C}$ then centrifuged at $38000 \mathrm{~g}$ for $1 \mathrm{~h}$. The membrane pellets were washed twice with distilled water and stored at $-20^{\circ} \mathrm{C}$. Protein determinations on the isolated OMs were by the method of Lowry $e t a l{ }^{27}$

\section{Sodium dodecyl sulphate-polyacrylamide gel electrophoresis ( $S D S-P A G E$ )}

OM preparations were separated by SDS-PAGE with an acrylamide $14 \%$ running gel and a $5 \%$ stacking gel as described previously. ${ }^{28}$ Gels were stained with silver $^{29}$ or with Commassie Brilliant Blue (Sigma) $0 \cdot 1 \%$. Molecular weights $\left(M_{r} s\right)$ of separated proteins

Table I. Strains of $P$. aeruginosa isolated from CF sputum samples

\begin{tabular}{rlcl}
\hline Strain no. & Phenotype & O serotype & Phage type \\
\hline 6680 & Mucoid & 3 & $21 / 44 / \mathrm{F} 8 / 109 / 1214 / \mathrm{Col} 2 / \mathrm{Col} 21 \mathrm{n}$ \\
1118 & Non-mucoid & 3 & $7 / 21 / \mathrm{F} 7 / \mathrm{M} 4 / \mathrm{Col} 2 / \mathrm{Col} 11+$ \\
8815 & Mucoid & 10 & $21 / 68 / 73 / \mathrm{F} 8 / 108 / 352 / 1214+$ \\
170 & Mucoid & $3 / 9$ & $21 / 48 / 68 / \mathrm{F} 3 / 109 / 352 / 1214 / \mathrm{M} 4 / \mathrm{Col} 11+$ \\
1222 & Non-mucoid & $3 / 6 / 9 / 10$ & $7 / 109 / 352+$ \\
& & & \\
\hline
\end{tabular}


were estimated by comparison with the $\mathrm{M}_{\mathrm{r}}$ of known protein standards (Bio-Rad, Richmond, CA, USA). Gels for immunoblotting were cast without a comb to form a flat top as described previously. ${ }^{28}$ The loading of OM was $15 \mu \mathrm{g}$ of protein $/ 0.6 \mathrm{~cm}$ of the top surface.

\section{Immunoblotting}

Antigens were transferred from polyacrylamide gels to nitrocellulose (NC) paper (Schleicher and Schuell, Dassell, Germany) by a modification of the method of Towbin. ${ }^{30}$ Blotting was done in a Trans-Blot apparatus (Bio-Rad) at $90 \mathrm{~V}$ for $2 \mathrm{~h}$ with a cooling coil, then reduced to $30 \mathrm{~V}$ and continued overnight. The high initial voltage was found to be necessary to transfer the high $M_{r}$ IRMPs and did not adversely affect the transfer of other OMPs. After transfer of proteins the NC paper was cut into strips and antigenic sites were visualised as described previously. ${ }^{28}$ To show complete qualitative transfer of proteins from the polyacrylamide gel, some strips of NC paper were stained with colloidal gold (AuroDye, Jansen, Beerse, Belgium) immediately after transfer. $\mathbf{M}_{\mathbf{r}} \mathbf{s}$ of blotted proteins were determined by comparison with the $M_{r}$ of prestained protein standards (Bio-Rad).

\section{Preparation of $P$. aeruginosa standard antigen (StAg)}

Strains representing the 17 serotypes of $P$. aeruginosa were obtained from Mikkelsen ${ }^{31}$ and from the Cross Infection Laboratory, Public Health Laboratory Service, Colindale Avenue, London. Strains were grown on plates of agar containing peptone $5 \%$, glucose $0.2 \%$ and $\mathrm{NaCl} 0.5 \%, \mathrm{pH} 7.5$ (Truche Agar; State Serum Institute, Copenhagen) for $18 \mathrm{~h}$ at $35^{\circ} \mathrm{C}$. The cells were harvested with distilled water and centrifuged at $10000 \mathrm{~g}$ for $10 \mathrm{~min}$ at $4^{\circ} \mathrm{C}$. The bacterial pellet was resuspended in five volumes of distilled water and cells were broken by sonication at $20 \mathrm{KHz}$ for three 45 -s bursts in an ice bath. The sonicate was centrifuged at $38000 \mathrm{~g}$ for $1 \mathrm{~h}$. The supernate containing soluble antigens (StAg) was stored at $-20^{\circ} \mathrm{C}$ until use.

\section{Crossed immuno-electrophoresis (CIE)}

Precipitating antibodies against $P$. aeruginosa were determined by CIE. ${ }^{11}$ StAg samples were applied to wells punched in agarose $1 \%$ gels (Indubiose A 37 ; L'Industrie Biologique Francaise S.A., France) and separated in the first dimension at $10 \mathrm{~V} / \mathrm{cm}$ for $30 \mathrm{~min}$. Second dimension electrophoresis was at $1-2 \mathrm{~V} / \mathrm{cm}$ for $18 \mathrm{~h}$ into agarose $1 \%$ containing patient's serum at a concentration of $15 \mu \mathrm{l} / \mathrm{cm}^{2}$. Immunoprecipitates were stained with Coomassie Brilliant Blue and the number of precipitin peaks (precipitins) was counted.

\section{Immune sera}

Polyclonal antisera to StAg and to the OM of strain
6680 were prepared by hyperimmunisation of rabbits according to the method of Harboe and Ingild. ${ }^{32}$

\section{Results}

\section{Outer membrane of $P$. aeruginosa strain 6680}

The Coomassie Blue-stained gel of OMPs and core lipopolysaccharide (LPS) of strain 6680 after separation by SDS-PAGE (fig. 1a) conforms largely to the scheme described by Hancock and Carey. ${ }^{33}$ Proteins at $17,19,30$ and $52 \mathrm{Kda}$ in the $\mathrm{OM}$ of this strain are not characterised by letters in the Hancock and Carey scheme. In addition, iron deprivation induces four high- $\mathrm{M}_{\mathrm{r}}$ proteins, two major at 74 and $83 \mathrm{Kda}$ and two minor at 71 and $76 \mathrm{Kda} ; 34,35$ these could be repressed completely by inclusion of $0.12 \mathrm{mM}$ iron in the growth medium (data not shown). The more sensitive silver stain of the same preparation (fig. 1b) shows more clearly the protein bands at 17 and $19 \mathrm{Kda}$ and reveals a number of minor proteins not visible in the Coomassie Blue-stained gel. Both Coomassie Blue and silver stains show the amount of protein $\mathrm{Hl}$ in the $\mathrm{OM}$ of this strain to be greater than that of $\mathrm{H} 2$. All the protein bands visualised by the silver stain of the $O M$ could be seen in a direct gold stain of the NC paper after electrophoretic transfer (not shown) and after reaction with serum from rabbits immunised with the OM preparation (fig. 1c) and StAg (fig. 1d).

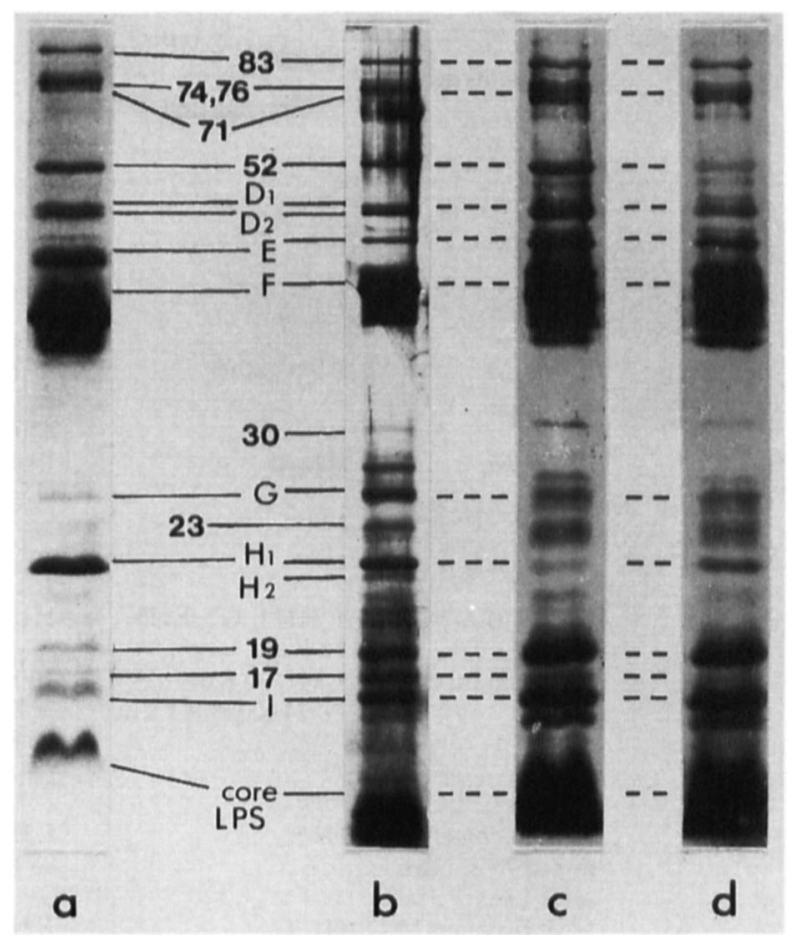

Fig. 1. The OM of $P$. aeruginosa strain 6680 separated by SDSPAGE and stained with Coomassie Brilliant Blue (a) and silver (b), or electrophoretically blotted to NC paper and incubated with rabbit antiserum to $\mathrm{OM}$ (c) or to $\mathrm{StAg}$ (d). Numbers in heavy type indicate the $\mathbf{M}_{\mathrm{r}}(\mathrm{Kda})$ of proteins not characterised by a letter in the scheme of Hancock and Carey. ${ }^{33}$ 


\section{CIE precipitins and clinical condition}

Serum samples from the nine infected $C F$ patients encompassed the progress of the disease from a time before infection through to the late stages of chronic broncho-pulmonary disease. The mean age of the patients at the time they became chronically infected with $P$. aeruginosa was $10 \cdot 7$ years (range 3.8-19.1 years). In all nine patients there was an increase in precipitin numbers during the first year of chronic infection. Four of the patients had a rapid increase (table II), which was defined as a rise of more than five precipitin lines a year. ${ }^{3}$ In another two patients the increase in precipitin numbers was rapid in the first year and then levelled off, in both cases at 14-17 precipitin lines; the numbers remained steady for the rest of the study period. The rapid rise in precipitin numbers was associated in all cases with isolation of mucoid strains of $P$. aeruginosa (table II) which was associated in these patients with a deterioration of lung function to $50-75 \%$ of normal predicted values and with stunting of growth. The clinical state of four of the six patients improved with intensive antibiotic treatment but deteriorated between treatments.

Three patients showed a slower overall rate of increase in precipitin numbers and in these patients normal weight gain and lung function were maintained with the onset of infection. In this group, infection was initially with non-mucoid strains, which were replaced by mucoid strains after a period of 1-4 years (table II). A rapid increase in the number of precipitin lines was seen at the same time as isolation of the mucoid form, but in only one of the three patients in this group was this associated with deterioration in lung function and weight loss.

\section{Longitudinal study of antibodies to OMPs by immunoblotting}

Sequential serum samples from the nine patients were allowed to react with OMs after immunoblotting. The earliest anti-OMP antibodies to appear in most patients were directed against proteins $\mathrm{Hl}$ and $\mathrm{G}$ (table II). In two patients, both in the group with a rapid initial rise in precipitins, antibodies to $\mathrm{Hl}$ appeared alone. In another five patients, antibodies to $\mathrm{Hl}$ were amongst the first to appear, most often in combination with antibodies to proteins $\mathrm{G}$ and I (table II). In seven of the patients, immunoblotting showed the presence of antibodies to protein $\mathrm{Hl}$ in serum before the appearance of CIE precipitins or the constant presence of $P$. aeruginosa in sputum. In two patients, antibodies to protein $\mathrm{G}$ also appeared at this early stage. The appearance of antibodies to other OMPs was co-incident with an increase in precipitins in the first year of chronic infection. Serum samples with eight or more precipitin peaks in CIE contained antibodies that reacted with all the major OMPs.

Table II. Antibodies to OMPs in the early stages of chronic $P$. aeruginosa lung infection in CF

\begin{tabular}{|c|c|c|c|c|c|}
\hline \multirow{2}{*}{$\begin{array}{l}\text { Increase } \\
\text { in CIE } \\
\text { precipitins }\end{array}$} & \multirow[b]{2}{*}{ Phenotype } & \multirow{2}{*}{$\begin{array}{l}\text { First OMP } \\
\text { antigen } \\
\text { recognised }\end{array}$} & \multicolumn{2}{|c|}{ At first isolation of $P$. aeruginosa } & \multirow{2}{*}{$\begin{array}{l}\text { Anti-OMP antibodies } \\
\text { at onset of chronic infection }\end{array}$} \\
\hline & & & $\begin{array}{l}\text { Anti-OMP } \\
\text { antibodies }\end{array}$ & $\begin{array}{l}\text { Number of } \\
\text { precipitins } \\
\text { (CIE) }\end{array}$ & \\
\hline \multicolumn{6}{|l|}{ Rapid } \\
\hline Patient a & $\mathbf{M}$ & I & I & 0 & $\begin{array}{l}\text { I, } 17 \mathrm{Kda}, 19 \mathrm{Kda}, \mathrm{H} 1, \mathrm{G}^{*}, \mathrm{~F}, \mathrm{E}, \mathrm{D}, \\
52 \mathrm{Kda}\end{array}$ \\
\hline b & $\mathbf{M}$ & H1 & H1 & 0 & $\begin{array}{l}\text { I, } 7 \mathrm{Kda}, 19 \mathrm{Kda}, \mathrm{H} 2, \mathrm{H} 1, \mathrm{G}, \mathrm{F}, \mathrm{D}^{*} \text {, } \\
52 \mathrm{Kda}, 74 \mathrm{Kda}, 83 \mathrm{Kda}^{*}\end{array}$ \\
\hline c & $\mathbf{M}$ & All together & $\begin{array}{l}17 \mathrm{Kda}, \mathrm{G}, 30 \mathrm{Kda}, \mathrm{F} \text {, } \\
\mathrm{E}, \mathrm{D}, 52 \mathrm{Kda}, 74 \mathrm{Kda} \\
83 \mathrm{Kda}\end{array}$ & 7 & $\begin{array}{l}\text { I, G, } 30 \mathrm{Kda}, \mathrm{F}, \mathrm{E}, \mathrm{D}, 52 \mathrm{Kda}, 74 \\
\mathrm{Kda}, 83 \mathrm{Kda}\end{array}$ \\
\hline $\mathrm{d}$ & $\mathbf{M}$ & H1 & $\begin{array}{l}19 \mathrm{Kda}, \mathrm{I}, \mathrm{H} 1, \mathrm{~F}, \mathrm{E}^{*} \\
\mathrm{D}^{*}, 52 \mathrm{Kda}\end{array}$ & 4 & $19 \mathrm{Kda}, \mathrm{I}, \mathrm{H} 1, \mathrm{~F}, \mathrm{E}^{*}, \mathrm{D}^{*}, 52 \mathrm{Kda}$ \\
\hline \multicolumn{6}{|l|}{$\begin{array}{l}\text { Initially rapid, } \\
\text { then slow }\end{array}$} \\
\hline Patient e & Mixed M \& NM & $\begin{array}{l}\mathrm{I}, \mathrm{H} 1^{*} 1, \mathrm{G}^{*}, \mathrm{E}, \mathrm{D} \\
52 \mathrm{Kda}\end{array}$ & H1, G, E, D & 0 & $\begin{array}{l}19 \mathrm{Kda}, \mathrm{I}, \mathrm{H} 2, \mathrm{H} 1, \mathrm{G}, \mathrm{E}, \mathrm{D}, 52 \mathrm{Kda}, \\
74 \mathrm{Kda}^{*}, 83 \mathrm{Kda}^{*}\end{array}$ \\
\hline f & $\begin{array}{l}\text { NM then mixed } \mathbf{M} \\
\text { \& NM }\end{array}$ & $\begin{array}{l}\mathrm{I}, \mathrm{H} 1,30 \mathrm{Kda}^{*}, \mathrm{~F}, \mathrm{E} \\
\mathrm{D}, 74 \mathrm{Kda}^{*}, 83 \mathrm{Kda}^{*}\end{array}$ & $\begin{array}{l}19 \mathrm{Kda}, \mathrm{I}, \mathrm{Hl}, 30 \mathrm{Kda} \\
\mathrm{F}, \mathrm{D}, 52 \mathrm{Kda}, 74 \mathrm{Kda} \\
83 \mathrm{Kda}\end{array}$ & 0 & $\begin{array}{l}19 \mathrm{Kda}, \mathrm{I}, \mathrm{H} 1, \mathrm{G}, 30 \mathrm{Kda}, \mathrm{F}, \mathrm{E}, \mathrm{D} \\
52 \mathrm{Kda}, 74 \mathrm{Kda}, 83 \mathrm{Kda}\end{array}$ \\
\hline \multicolumn{6}{|l|}{ Slow } \\
\hline Patient $\mathrm{g}$ & $\begin{array}{l}\text { NM, becomes } \\
\text { mixed } \mathbf{M} \& \mathbf{N M} \\
\text { after } 1 \text { year }\end{array}$ & $\mathrm{H} 1 * 1$ & $\begin{array}{l}\text { I, H1, } 52 \mathrm{Kda}, 74 \mathrm{Kda}^{*} \\
83 \mathrm{Kda}^{*}\end{array}$ & 1 & $\begin{array}{l}\mathrm{I}, \mathrm{H} 1,30 \mathrm{Kda}, \mathrm{F}^{*}, \mathrm{D}, \mathrm{E}, 52 \mathrm{Kda}, 74 \\
\mathrm{Kda}^{*}, 83 \mathrm{Kda}^{*}\end{array}$ \\
\hline h & $\begin{array}{l}\text { NM, becomes } \mathrm{M} \\
\text { after } 4 \text { years }\end{array}$ & $\mathrm{H} 1, \mathrm{G}$ & $\mathrm{I}, \mathrm{H} 1, \mathrm{G}, 30 \mathrm{Kda}$ & 2 & $\mathrm{I}, \mathrm{Hl}, \mathrm{G}, 30 \mathrm{Kda}, \mathrm{F}^{*}$ \\
\hline $\mathrm{i}$ & $\begin{array}{l}\mathrm{NM} \text {, becomes } \mathrm{M} \\
\text { after } 2 \text { years }\end{array}$ & All together & I, H1, F, E, D & 3 & $17 \mathrm{Kda}, \mathrm{I}, \mathrm{H} 1, \mathrm{~F}, \mathrm{E}, \mathrm{D}$ \\
\hline
\end{tabular}

M, mucoid; NM, non-mucoid.

* Indicates a faint reaction. 
The pattern of appearance of antibodies to OMPs differed in patients with slow or rapid increases in precipitin numbers. Figs 2, 3 and 4 show reactions of OM antigens with sera from three of the patients. Patient i (fig. 2) was from the group with a slow initial increase in precipitin numbers (table II). In this patient's sera, no antibodies to OMPs were detected by immunoblotting before the presence of CIE precipitins (fig. 2, strips 1 and 2). By the time that three precipitins were detected by CIE, immunoblotting showed antibodies to OMPs D, E, F, Hl and I. Thereafter, antibodies appeared to the $17-\mathrm{Kda}$ protein (fig. 2, strip 5). Antibodies to IRMPs appeared weakly when there were three precipitins (fig. 2, strip 4). It was not possible to distinguish the four individual IRMPs due to their closely similar $\mathbf{M}_{\mathrm{r}} \mathbf{s}$ and they are labelled with the $M_{r}$ of the two major proteins. The number of antibodies and the intensity of the reaction (as judged by the density of the colour reaction) did not increase greatly with the increase in precipitins, nor with the isolation of the mucoid form. In patients $\mathrm{g}$ and $\mathrm{h}$, however, there was a marked increase in the intensity of the reaction to core-LPS and to the 52$\mathrm{Kda}$ protein with isolation of the mucoid form (fig. 3, patient $h$ ). In this patient, antibodies to proteins $\mathrm{Hl}$ and $G$ were recognised by immunoblotting before there was a CIE precipitin response. Antibodies to the other major OMPs appeared as precipitin numbers increased and all were visualised by immunoblotting of the serum sample with nine precipitins (fig. 3, strip 5). Antibodies to IRMPs were present from this time onwards but did not react strongly. This was the only patient in the present study whose serum precipitins consistently decreased after reaching a maximum. The decrease did not correlate with a decrease in the number of blotted bands (fig. 3, strips 11-14). However, the patient did improve clinically.

The number of antigens recognised and the intensity

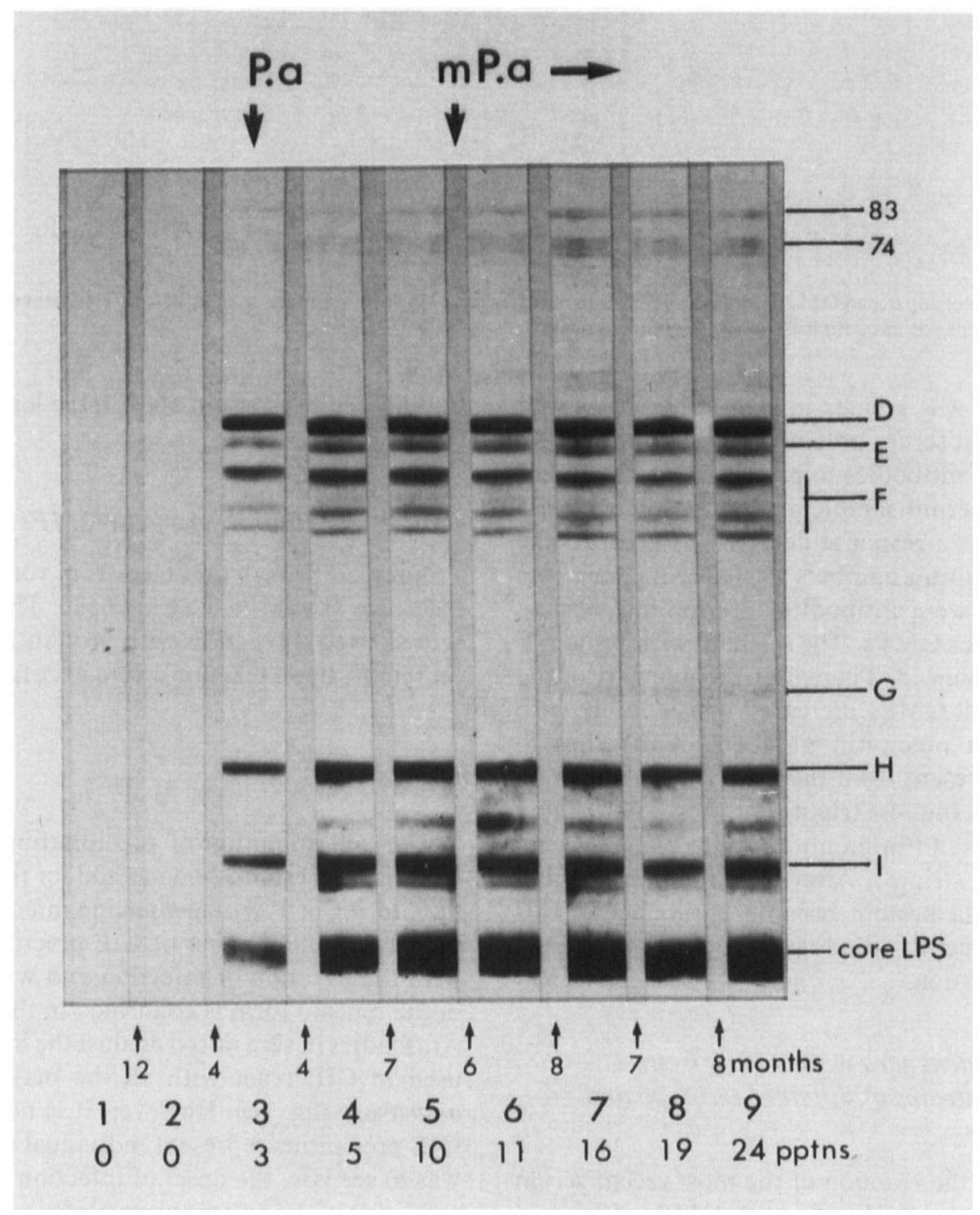

Fig. 2. Immunoblots of separated OM components of strain 6680 after reaction with serum from an infected CF patient (i) in stable clinical condition. P.a indicates the first isolation of $P$. aeruginosa from patient's sputum; $\mathbf{m P . a}$ indicates isolation of mucoid $P$. aeruginosa. The interval in months between subsequent serum samples is given below the blots $(\uparrow)$. The lower line shows precipitin numbers in each serum sample (pptns). 


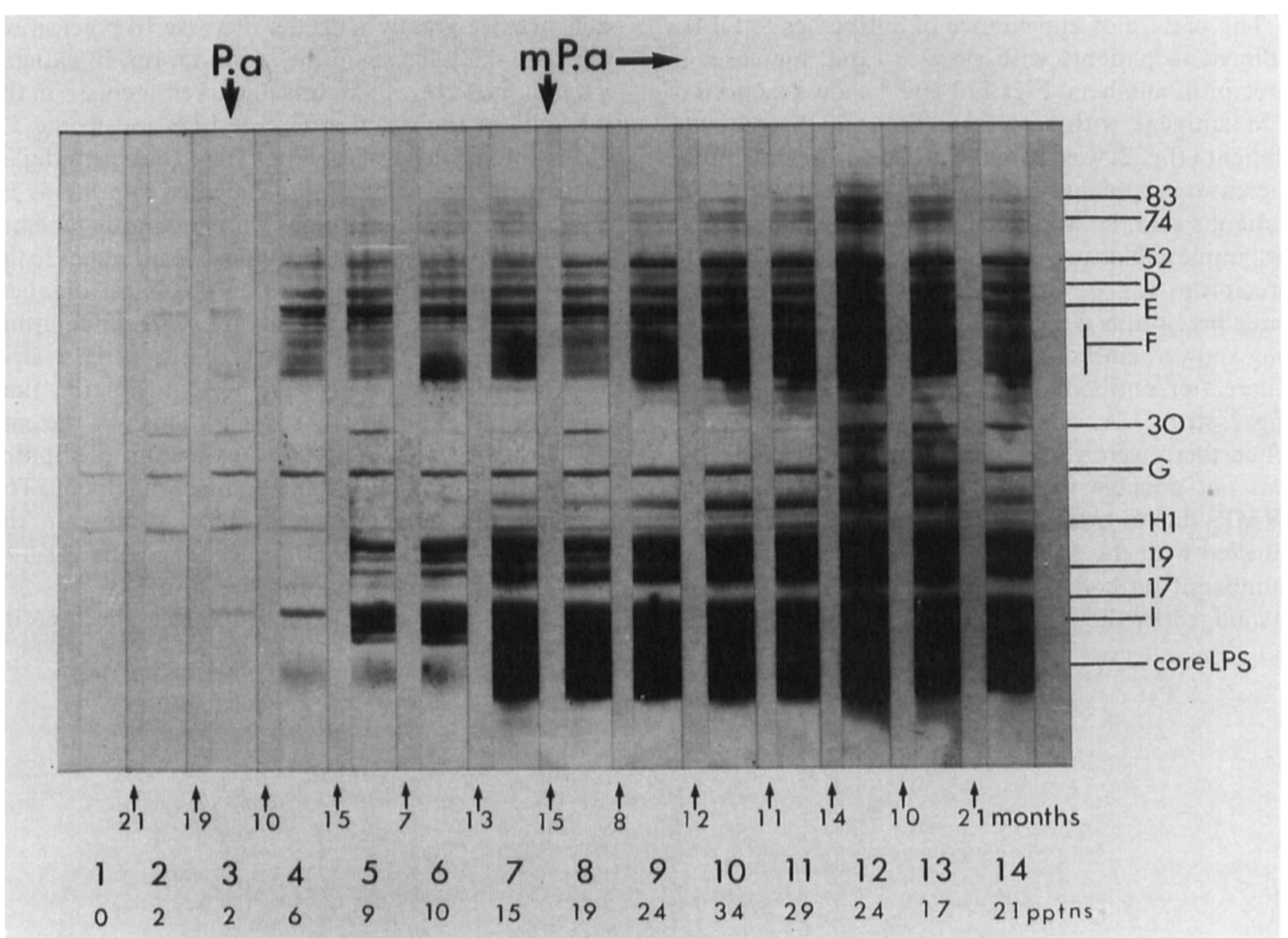

Fig. 3. Immunoblots of separated OM components of strain 6680 after reaction with serum from an infected CF patient (h). Serum antibody levels increased in this patient with isolation of the mucoid form.

of the reaction was greater in those patients with a rapid increase in serum precipitins (fig. 4 , patient d). In this patient, antibodies to protein $\mathrm{Hl}$ were present in the earliest serum sample available, some 3 years before there was a response detected by CIE. At the time when precipitin numbers started to increase (fig. 4, strip 4) there were antibodies in serum that reacted with all the major OMPs. The reaction with protein $F$ was most pronounced. Thereafter the intensity of the reaction with all OMPs increased considerably with the increase in precipitin numbers. Antibodies to IRMPs were present from the time when there were four precipitins (fig. 4, strip 4) but they reacted only weakly until precipitin numbers in the high 30 s were reached (fig. 4, strip 8). After this time the reaction with the $83-\mathrm{Kda}$ protein became pronounced. This patient subsequently died as a result of chronic pulmonary infection.

\section{Reaction of patient sera with OMPs from $P$. aeruginosa strains of different serotype and phenotype}

Fig. 5 shows the reaction of the most recent serum samples from patients $d$ and $i$ with OMPs of mucoid and non-mucoid organisms of $\mathrm{O}$-serotypes commonly isolated in the Danish CF Centre. ${ }^{36}$ The pattern of reaction of both sera with all four strains was similar to that seen with strain 6680 in the longitudinal study (figs. 2 and 4).

\section{Reaction of control sera with OMPs}

None of the sera obtained from young CF patients reacted with OMPs of strain 6680 . Three of the adult sera showed a reaction with protein $\mathrm{H}$ and one with protein $\mathrm{F}$; these reactions were very faint.

\section{Discussion}

The determination of precipitating antibodies by CIE is a well established method for the diagnosis and monitoring of $\boldsymbol{P}$. aeruginosa lung infection in CF. ${ }^{3}$ An increase in the number of CIE precipitins with time, with the duration of infection and with the isolation of the mucoid form is confirmed in the present study. Antibodies in sera raised against the StAg preparation used in CIE react with all the major OMPs of $P$. aeruginosa (fig. 1d). However, it is not known which CIE precipitins represent individual OMPs. Our aim was to see how the onset of infection and the clinical condition of the patient were related to the appearance of antibodies to OMPs. The study was continued for periods up to 15 years in individual patients, but the later findings may not represent the natural history of 


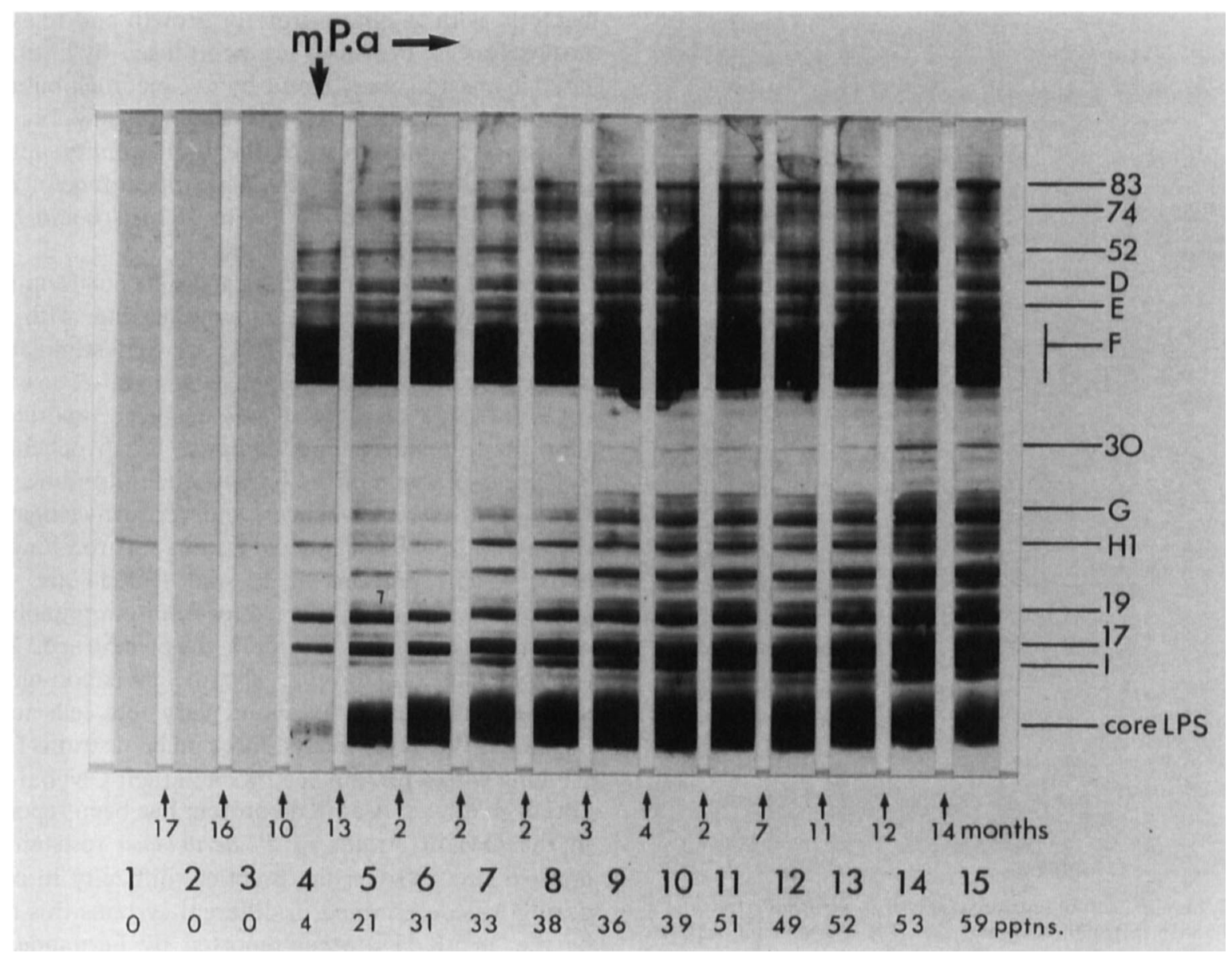

Fig. 4. Immunoblots of separated $O M$ components of strain 6680 after reaction with serum from a patient in poor clinical condition (d).

the lung infection because all patients were treated with anti-pseudomonal antibiotics after the diagnosis of chronic lung infection was made.

In the nine patients studied by immunoblotting, the appearance of antibodies to most OMPs was coincident with the appearance of CIE precipitins. Immunoblotting showed antibodies to some OMPs before the appearance of CIE precipitins; this may reflect the greater sensitivity of the immunoblotting technique. ${ }^{28}$ Proteins G, $\mathrm{Hl}$ and $\mathrm{I}$ in particular were likely to appear in immunoblotting before CIE precipitins and may thus be useful markers for the onset of infection. In the early stages of infection an increase in precipitin numbers was accompanied by an increase in the number of antibodies to OMPs detected by immunoblotting. There was, however, no direct correlation between the number of antibodies against OMPs detected by immunoblotting and CIE precipitin numbers (table II). This is probably because the StAg used in CIE is a whole cell preparation. We have previously shown a good correlation between precipitin numbers and anti-LPS antibody concentrations determined by ELISA. ${ }^{37} \mathrm{~A}$ rapid increase in antibodies to OMPs detected by immunoblotting paralleled a rapid increase in precipitins which is associated with a poor prognosis. ${ }^{3}$ This study shows that a pronounced antibody response to OMPs of $\boldsymbol{P}$. aeruginosa does not lead to the resolution of CF lung infection. Persistent infection and a continuous antibody response may lead to immune-complex formation and is consistent with the theory that immune complexes are implicated in the pathogenesis of $\mathrm{CF}$ lung disease.

A previous study of $P$. aeruginosa isolated directly from the lungs of a patient with $\mathrm{CF}^{24}$ showed the cells to be growing in conditions of iron limitation. Antibodies to IRMPs were detected in the patient's serum. ${ }^{23,24}$ In the present study, antibodies to IRMPs did not appear early in the infection in any of the patients studied and were detected at high concentrations only in seriously ill patients. This is in agreement with the report of Kubesch et al..$^{38}$ and that of Brown et $a l^{24}$ whose CF patient had had chronic lung infection for 8 years. This was an unexpected observation if it is assumed that the IRMPs are necessary for iron uptake and hence bacterial growth.

It is not known why the antibody response to IRMPs should appear late in $P$. aeruginosa lung infection. The level of free iron in the lung is well below that required for bacterial growth. ${ }^{39}$ IRMPs are certainly immunogenic, because immunisation of rabbits with OMs isolated from cells grown in ironlimited conditions causes formation of antibodies to IRMPs (fig. 1c) within a few weeks. It is possible that the mucoid exopolysaccharide characteristic of strains infecting the CF lung, or the microcolony mode of 


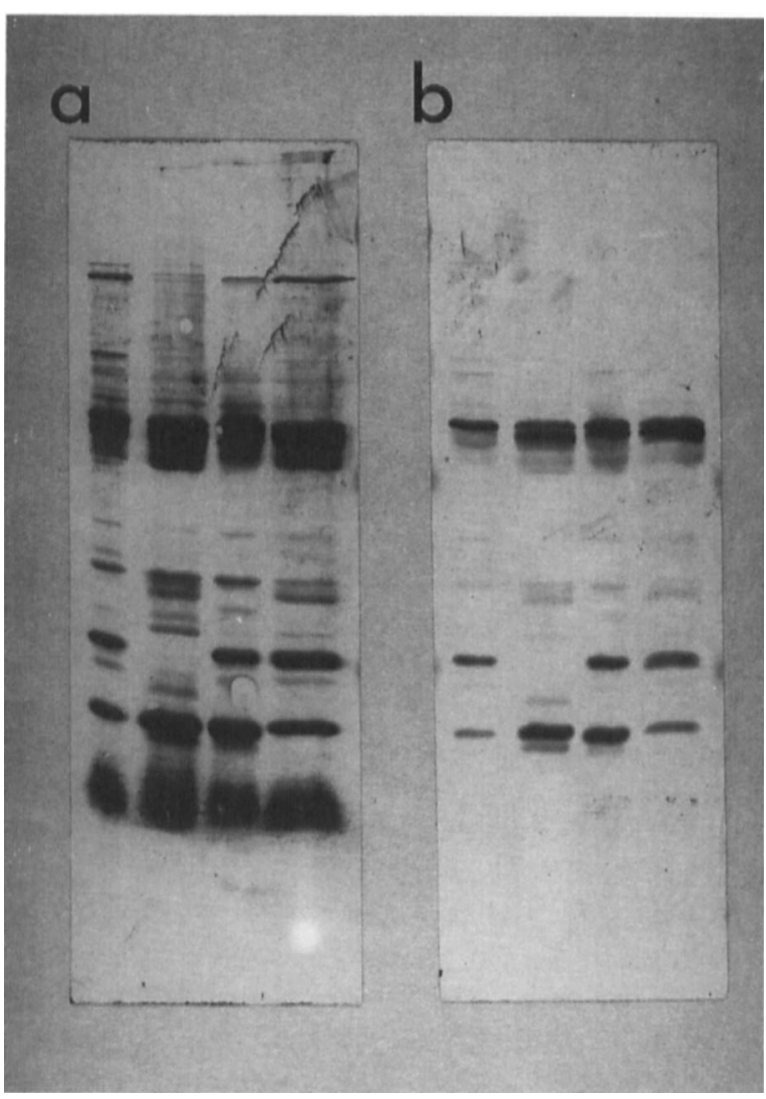

Fig. 5. Immunoblots of separated OMs of $P$. aeruginosa strains 1118 (NM), $8815(\mathrm{M}), 170(\mathrm{NM})$ and $1222(\mathrm{M})$ after reaction with late serum samples from patients $d(a)$ and $i(b)$.

growth, ${ }^{40}$ masks the surface of the bacteria ${ }^{41}$ or alters the dynamics of iron uptake. The $\mathrm{pH}$ in the CF lung appears to be neutral, ${ }^{42}$ but acid metabolic products and a local inflammatory response may lower the $\mathrm{pH}$ in the mucoid microcolony to the optimum for iron uptake by pyoverdin and pyochelin siderophores. ${ }^{43}$ However, this explanation is in conflict with the observation that infection in CF is initially with classical non-mucoid strains which become mucoid only later. IRMPs may, in fact, not be expressed until late in the infection. Protease enzymes secreted by $P$. aeruginosa have been shown to cleave transferrin and make iron available to the bacteria. ${ }^{44}$ Transferrin has been shown to be present in CF lung fluid. ${ }^{45}$ The production of proteases is known to be stimulated by growth in iron-limited conditions. ${ }^{46,47} P$. aeruginosa proteases are also reported to inhibit lymphocyte function. ${ }^{48}$ Secretion of proteases early in the infection may thus be a virulence mechanism which allows the

\section{References}

1. Bodey GP, Bolivar R, Fainstein V, Jadeja L. Infections caused by Pseudomonas aeruginosa. Rev Infect Dis 1983; 5: 279313.

2. Govan JRW, Harris GS. Pseudomonas aeruginosa and cystic fibrosis: unusual bacterial adaptation and pathogenesis. Microbiol Sci 1986; 3: 302-308. bacteria both to obtain iron for growth and to avoid host defences. Proteases are neutralised by antibody later in the infection ${ }^{49}$ and by $\alpha 2$-macroglobulin in serum transudates. ${ }^{6}$ At this stage it may become necessary to make use of the high affinity uptake system and express IRMPs. The appearance of high concentrations of antibodies to IRMPs could be a marker of more advanced illness.

The OM of the mucoid clinical isolate 6680 contains some atypical proteins. Immunoblotting with $\mathrm{CF}$ serum shows them to be antigens that stimulate a considerable antibody response in vivo. A low $\mathbf{M}_{r}$ (14 Kda) OMP of $P$. aeruginosa has been reported to bind the iron-siderophore complex, ferripyochelin. ${ }^{50}$ Surface expression of the ferripyochelin-binding protein is required for virulence ${ }^{21}$ and we are investigating the low $M_{r}$ OMPs of mucoid strains for iron binding activity. The proteins at 17 and $19 \mathrm{Kda}$ are very similar in $M_{r}$ to that reported for pili in immunoblots of $P$. aeruginosa $\mathrm{OM}^{51}$ Similarly the protein at $52 \mathrm{Kda}$ could be flagella. However, strain 6680 is non-motile and electronmicroscopy shows very few cells to be flagellate. We have isolated three mucoid strains from CF lung with a protein at $52 \mathrm{Kda}$ in their OM but it is absent in others. A 54-Kda protein has been reported in the OM of strains of $P$. aeruginosa resistant to norfloxacin. ${ }^{52}$ Given the practical difficulty in comparing $\mathbf{M}_{\mathrm{r}} \mathrm{s}$ determined in different systems this may be the $58.5-\mathrm{Kda}$ protein reported by Fernandes to cause an antibody response in CF serum. ${ }^{17}$ Proteins at 23 and $30 \mathrm{Kda}$ in the OM of strain 6680 produced an antibody response which increased in the later stages of infection (figs. 3 and 4). A $32-\mathrm{Kda}$ protein has been reported previously in the OM of antibioticsusceptible mucoid strains ${ }^{53}$ and has also been shown to be associated with serum sensitivity. ${ }^{54}$ This may be the protein we see at $30 \mathrm{Kda}$. It is possible that these unusual OMPs are selected by intensive antibiotic treatment of the lung infection. We are currently investigating the antibiotic sensitivity of mucoid strains with these atypical proteins in the outer membrane. The antibody response to these unfamiliar OMPs emphasises the importance of investigations with clinical isolates grown in iron-limited conditions because laboratory strains grown in iron-rich complex media may not express surface antigens characteristic of cells growing in vivo. ${ }^{55}$

G.H.S. was supported by grants from the Leo Research Fund and the Egmont Pedersen Fund.
3. Høiby N. Pseudomonas aeruginosa infection in cystic fibrosis. Diagnostic and prognostic significance of Pseudomonas aeruginosa precipitins determined by crossed immunoelectrophoresis. A survey. Acta Pathol Microbiol Scand Sect C 1977; Suppl 262: 3-96.

4. Cash HA, Straus DC, Bass JA. Pseudomonas aeruginosa exoproducts as pulmonary virulence factors. Can J Microbiol $1983 ; 29: 448-456$. 
5. Woods DE, Iglewski BH. Toxins of Pseudomonas aeruginosa: new perspectives. Rev Infect Dis 1983; 5: Suppl: S715S722.

6. Goldstein W, Döring G. Lysosomal enzymes from polymorphonuclear leukocytes and proteinase inhibitors in patients with cystic fibrosis. Am Rev Respir Dis 1986; 134: 49-56.

7. Høiby N. Döring G, Schiøtz PO. Pathogenic mechanisms of chronic Pseudomonas aeruginosa infections in cystic fibrosis patients. Antibiot Chemother 1987; 39: 60-76.

8. Høiby $\mathbf{N}$. Microbiology of lung infections in cystic fibrosis patients. Acta Paediatr Scand 1982; Suppl 301 : 33-54.

9. Pedersen SS, Jensen T, Høiby N, Koch C, Flensborg EW. Management of Pseudomonas aeruginosa lung infection in Danish cystic fibrosis patients. Acta Paediatr Scand 1987; 76: 955-961

10. Szaff M, Høiby N, Flensborg EW. Frequent antibiotic therapy improves survival of cystic fibrosis patients with chronic Pseudomonas aeruginosa infection. Acta Paediatr Scand $1983 ; 72: 651-657$

11. Høiby N. Antibodies against Pseudomonas aeruginosa in serum from normal persons and patients colonized with mucoid or non-mucoid Pseudomonas aeruginosa: results obtained by means of crossed immunoelectrophoresis. Acta Pathol Microbiol Scand Sect C 1977; 85: 142-148.

12. Høiby N, Andersen V, Bendixen G. Pseudomonas aeruginosa infection in cystic fibrosis. Humoral and cellular immune responses against Pseudomonas aeruginosa. Acta Pathol Microbiol Scand Sect C 1975; 83: 459-468.

13. Fomsgaard A, Conrad RS, Galanos C, Shand GH, Høiby N. Comparative immunochemistry of lipopolysaccharides from typable and polyagglutinable Pseudomonas aeruginosa strains isolated from patients with cystic fibrosis. $J$ Clin Microbiol 1988; 26: 821-826.

14. Cryz SRJ. Pseudomonas aeruginosa infections. In: Germanier R (ed) Bacterial vaccines. Orlando, Academic Press. 1984: 317-351.

15. Mutharia LM, Nicas TI, Hancock REW. Outer membrane proteins of Pseudomonas aeruginosa serotype strains. $J$ Infect Dis 1982; 146: 770-779.

16. Aronoff SC, Stern RC. Serum IgG antibody to outer membrane antigens of Pseudomonas cepacia and Pseudomonas aeruginosa in cystic fibrosis. $J$ Infect Dis $1988 ; 157: 934-940$.

17. Fernandes PB, Kim C, Cundy KR, Huang NN. Antibodies to cell envelope proteins of Pseudomonas aeruginosa in cystic fibrosis patients. Infect Immun 1981; 33: 527-532.

18. Hancock REW, Mouat ECA, Speert DP. Quantitation and identification of antibodies to outer-membrane proteins of Pseudomonas aeruginosa in sera of patients with cystic fibrosis. J Infect Dis 1984; 149: 220-226.

19. Griffiths E. The iron-uptake systems of pathogenic bacteria. In: Bullen JJ, Griffiths E (eds) Iron and infection. Chichester, John Wiley and Sons. 1987: 69-137.

20. Cox CD. Effect of pyochelin on the virulence of Pseudomonas aeruginosa. Infect Immun 1982; 36: 17-23.

21. Sokol PA. Surface expression of ferripyochelin-binding protein is required for virulence of Pseudomonas aeruginosa. Infect Immun 1987; 55: 2021-2025.

22. Neilands JB. Microbial envelope proteins related to iron. Ann Rev Microbiol 1982; 36: 285-309.

23. Anwar H, Brown MRW, Day A, Weller PH. Outer membrane antigens of mucoid Pseudomonas aeruginosa isolated directly from the sputum of a cystic fibrosis patient. FEMS Microbiol Lett 1984; 24 : 235-239.

24. Brown MRW, Anwar H, Lambert PA. Evidence that mucoid Pseudomonas aeruginosa in the cystic fibrosis lung grows under iron restricted conditions. FEMS Microbiol Lett $1984 ; 21$ : 113-117.

25. Wood RE, Boat TF, Doershuk CF. Cystic fibrosis. Am Rev Respir Dis 1976; 113 : 833-878.

26. Filip C, Fletcher G, Wulff JL, Earhart CF. Solubilization of the cytoplasmic membrane of Escherichia coli by the ionic detergent sodium-lauryl sarcosinate. J Bacteriol 1973; 115: 717-722.

27. Lowry OH, Rosebrough NJ, Farr AJ, Randall RJ. Protein measurements with the folin phenol reagent. J Biol Chem $1951 ; 193: 265-275$.

28. Shand GH, Pedersen SS, Tilling R, Brown MRW, Høiby N. Use of immunoblot detection of serum antibodies in the diagnosis of chronic Pseudomonas aeruginosa lung infection in cystic fibrosis. $J$ Med Microbiol 1988; 27: 169-177.

29. Oakley BR, Kirsch DR, Morris NR. A simplified ultrasensitive silver stain for detecting proteins in polyacrylamide gels. Anal Biochem 1980; 105: 361-363.

30. Towbin H, Staehelin T, Gordon J. Electrophoretic transfer of proteins from polyacrylamide gels to nitrocellulose sheets: procedure and some applications. Proc Natl Acad Sci USA $1979 ; 76: 4350-4354$.

31. Mikkelsen OS. Serotyping of Pseudomonas aeruginosa 2. Results of an O group classification. Acta Pathol Microbiol Scand Sect $B$ 1970; 78 : 163-175.

32. Harboe NMG, Ingild A. Immunization, isolation of immunoglobulins and antibody titre determination. Scand $J$ Immunol 1983; 17 Suppl 10: 345-352.

33. Hancock REW, Nikaido H. Outer membranes of gram-negative bacteria. J Bacteriol 1978; 136: 381-390.

34. Meyer JM, Mock M, Abdallah MA. Effect of iron on the protein composition of the outer membrane of fluorescent pseudomonads. FEMS Microbiol Lett 1979; 5: 395-398.

35. Ohkawa I, Shiga S, Kageyama M. Effect of iron concentration in the growth medium on the sensitivity of Pseudomonas aeruginosa to pyocin S2. J Biochem 1980; 87: 323-331.

36. Zimakoff J, Høiby N, Rosendal K, Guilbert JP. Epidemiology of Pseudomonas aeruginosa infection and the role of contamination of the environment in a cystic fibrosis clinic. $J$ Hosp Infect 1983; 4: 31-45.

37. Fomsgaard A, Høiby N, Shand GH, Conrad RS, Galanos C. Longitudinal study of antibody response to lipopolysaccharides during chronic Pseudomonas aeruginosa lung infection in cystic fibrosis. Infect Immun 1988; 56: 2270 2278.

38. Kubesch $\mathbf{P}$, Von Specht B-U, Tümmler B. Immune response in cystic fibrosis to outer membrane proteins of Pseudomonas aeruginosa. Zentralbl Bakteriol Mikrobiol Hyg [A] 1988; 269: 395-410.

39. Kilbourn JP. Composition of sputum from patients with cystic fibrosis. Curr Microbiol 1984; 11 : 19-22.

40. Lam J, Chan R, Lam K, Costerton JW. The production of mucoid microcolonies by Pseudomonas aeruginosa within infected lungs in cystic fibrosis. Infect Immun 1980; 28: $546-556$.

41. Marrie TJ, Harding GKM, Ronald AR et al. Influence of mucoidy on antibody coating of Pseudomonas aeruginosa. $J$ Infect Dis 1979; 139: 357-361.

42. Levy J, Smith AL, Kenny MA, Ramsey B, Schoenkneckt FD. Bio-activity of gentamicin in purulent sputum from patients with cystic fibrosis or bronchiectasis: comparison with activity in serum. $J$ Infect Dis $1983 ; 148$ : 1069-1076.

43. Cox CD. Iron transport and serum resistance in Pseudomonas aeruginosa. Antibiot Chemother 1985; 36: 1-12.

44. Döring G, Pfestorf M, Botzenhart K, Abdallah MA. Impact of proteases on iron uptake of Pseudomonas aeruginosa pyoverdin from transferrin and lactoferrin. Infect Immun 1988; 56: 291-293.

45. Fick RB, Naegel GP, Squier SU, Wood RE, Gee BL, Reynolds HY. Proteins of the cystic fibrosis respiratory tract. $J$ Clin Invest 1984; 74 : 236-248.

46. Bjorn MJ, Sokol PA, Iglewski BH. Influence of iron on yields of extracellular products in Pseudomonas aeruginosa cultures. J Bacteriol 1979; 138: 193-200.

47. Ombaka EA, Cozens RM, Brown MW. Influence of nutrient limitation of growth on stability and production of virulence factors of mucoid and nonmucoid strains of Pseudomonas aeruginosa. Rev Infect Dis 1983; 5 Suppl 5: S880-S887.

48. Theander TG, Kharazmi A, Pedersen BK et al. Inhibition of human lymphocyte proliferation and cleavage of interleukin-2 by Pseudomonas aeruginosa proteases. Infect Immun 1988 ; 56: 1673-1677.

49. Döring G, Høiby N. Longitudinal study of immune response to Pseudomonas aeruginosa antigens in cystic fibrosis. Infect Immun 1983; 42: 197-201.

50. Sokol PA, Woods DE. Demonstration of an iron-siderophorebinding protein in the outer membrane of Pseudomonas aeruginosa. Infect Immun 1983; 40: 665-669.

51. Watts TH, Worobec EA, Paranchych W. Identification of pilin pools in the membranes of Pseudomonas aeruginosa. $J$ Bacteriol $1982 ; 152$ : 687-691. 
52. Hirai K, Suzue S, Irikura T, Iyobe S, Mitsuhashi S. Mutation producing resistance to norfloxacin in Pseudomonas aeruginosa. Antimicrob Agents Chemother 1987; 31: 582-586.

53. Irvin RT, Govan JWR, Fyfe JAM, Costerton JW. Heterogeneity of antibiotic resistance in mucoid isolates of Pseudomonas aeruginosa obtained from cystic fibrosis patients : role of outer membrane proteins. Antimicrob Agents Chemother 1981; 19: 1056-1063.
54. Schiller NL, Hackley DR, Morrison A. Isolation and characterization of serum-resistant strains of Pseudomonas aeruginosa derived from serum-sensitive parental strains. Curr Microbiol 1984; 10: 185-189.

55. Brown MRW, Williams P. The influence of environment on envelope properties affecting survival of bacteria in infection. Annu Rev Microbiol 1985; 39: 527-556. 